\title{
Neuropsychopathological comorbidities in learning disorders
}

\author{
Lucia Margari", Maura Buttiglione, Francesco Craig, Arcangelo Cristella, Concetta de Giambattista, Emilia Matera,
} Francesca Operto and Marta Simone

\begin{abstract}
Background: Learning Disorders (LD) are complex diseases that affect about 2-10\% of the school-age population. We performed neuropsychological and psychopathological evaluation, in order to investigate comorbidity in children with LD.

Methods: Our sample consisted of 448 patients from 7 to 16 years of age with a diagnosis of LD, divided in two subgroups: Specific Learning Disorders (SLD), including reading, writing, mathematics disorders, and Learning Disorders Not Otherwise Specified (LD NOS).

Results: Comorbidity with neuropsychopathologies was found in $62.2 \%$ of the total sample. In the LSD subgroup, ADHD was present in 33\%, Anxiety Disorder in 28.8\%, Developmental Coordination Disorder in 17.8\%, Language Disorder in $11 \%$ and Mood Disorder in $9.4 \%$ of patients. In LD NOS subgroup, Language Disorder was present in 28.6\%, Developmental Coordination Disorder in 27.5\%, ADHD in 25.4\%, Anxiety Disorder in 16.4\%, Mood Disorder in $2.1 \%$ of patients. A statistically significant presence was respectively found for Language and Developmental Coordination Disorder comorbidity in LD NOS and for ADHD, mood and anxiety disorder comorbidity in SLD subgroup.
\end{abstract}

Conclusions: The different findings emerging in this study suggested to promote further investigations to better define the difference between SLD and LD NOS, in order to improve specific interventions to reduce the long range consequences.

Keywords: Learning disorders, Comorbidity, Language disorder, Motor coordination disorder, ADHD, Mood and anxiety disorders

\section{Background}

Learning Disorders (LD) affect about 2-10\% of the school-age population. They are characterized by an academic functioning that is below the level that would be expected given their age, Intelligent Quotient (IQ) and grade level in school, and interfere significantly with academic performances or daily life activities that require reading, writing or calculation skills. LD are distinguished in Specific Learning Disorders (SLD) and Learning Disorders Non-Otherwise Specified (LD NOS), two categories separated for the clinic and care. SLD include Reading, Written Expression and Calculation

\footnotetext{
* Correspondence: lucia.margari@uniba.it

Child Neuropsychiatry Unit, Department of Basic Medical Sciences,

Neurosciences and Sense Organs of the "Aldo Moro" University of Bari, Piazza Giulio Cesare 1, Bari, Italy
}

\section{Ciomed Central}

Disorder. LD NOS refer to a disability in acquiring new knowledge and skills, that are not limited to one or more specific school areas (reading, writing, mathematics) but also extended to other areas.

LD are neurobiological disorders that are not diagnosed before school age, accompanying the subject during the course of their life. Genetic and acquired factors may occur alone or in combination in determining LD. Dyslexia is present in $35-45 \%$ of ascending and collaterals; the concordance is $84 \%$ in monozygotic and $50 \%$ in dizygotic twins; moreover it has been demonstrated a genetic association with different chromosomes, including 6, 15, 18 [1-3], and about 15 genes have been found associated with dyslexia $[4,5]$. Recently, Giraud and Ramus [6] reviewed the current literature and described a putative mechanistic model that linked 
neuronal micro-architecture of the auditory cortex to specific alterations of phonological processing. The authors suggested that dyslexia could be related to a disconnection syndrome, signaling candidate genes (DCDC2, KIAA0319, DYX1C1) associated with neuroanatomical alterations, involving both the white and the gray matter of a frontotemporo-parietal network, suggestive of dysfunction in cortical connectivity. Several acquired factors have been also involved such as: childbirth dystocias, neonatal asphyxia, neonatal icterus, cardiorespiratory arrest, status epilepticus, low birth weight and preterm birth [7-9], smoker mother during pregnancy [10], exposure to more than 2 general anesthesia within the fourth year of life $[11,12]$, parental history of alcoholism or substance abuse [13] and prenatal exposure to cocaine [14]. School, family and social context are also interweave with neurobiological and contribute to determine the multifactorial nature of $\mathrm{LD}$.

LD show variable clinical features and often associate to other disorders [15], that complicate the LD clinical presentation. The knowledge of these aspects is important from a preventive and therapeutic point of view. For these reasons, in this study we analyzed comorbidities in LD, considering separately the SLD and LD NOS subgroups, in order to deepen clinical and etiopathogenic knowledge of these disorders and improve their treatment.

\section{Methods}

\section{Subjects}

The sample consisted of 448 patients with a diagnosis of Learning Disorder, formulated by a child and adolescent neuropsychiatrist. The patients were divided in 2 subgroups: SLD (including Reading, Writing and Calculation Disorders) and LD NOS. All participants had Italian as their first language and they referred to the Child Neuropsychiatric Unit of the University of Bari "Aldo Moro", Italy, during the period between October 2010 and December 2012. The study was approved by the local ethical committee "Azienda Ospedaliero-Universitaria Consorziale Policlinico di Bari”. All children were recruited in this study after obtaining written informed consent by their parents. In addition, patients aged from 8 to 16 years of age, gave their written informed consent.

All patients underwent anamnesis (familiar, physiological, pathological and academic), physical and neurological examination, routine laboratory tests and electroencephalogram.

\section{Assessment}

In this study we performed a clinical assessment of LD and specific comorbidities. Diagnosis was formulated, according to the diagnostic criteria of the Diagnostic and Statistical Manual of Mental Disorders Fourth EditionText Revision (DSM IV TR) [16], and it was supported by diagnostic standardized tests for neuropsychological and psychopathological evaluation.

Neuropsychological evaluation assessed cognitive level, reading, writing and arithmetic skills, visual motor abilities and language.

The cognitive level was assessed with Italian version of Wechsler Intelligence Scale for Children, Third Edition (WISC-III) [17], we could not use WISC IV [18] because it was validated for Italian language only on February 2012; Leiter International Performances Scale RevisedVisualization and Reasoning battery (Leiter-R) [19] was administered, as an alternative to WISC-III, to subjects with verbal disorders. The cognitive level was classified according to DSM IV TR criteria as follows: normal intellectual functioning, IQ $>84$; borderline intellectual functioning, IQ 71-84; mild intellectual impairment, IQ 50/55-70; moderate intellectual impairment, IQ 35/4050/55; severe intellectual impairment, IQ 20/25-35/40.

Academic achievement was assessed with the following batteries of tests, validated for the Italian language: MT Group Reading Tests for Primary School [20]; MT Group Reading Tests for Middle School [21]; MT Group Advanced Reading and Mathematics Tests [22] for the first biennium of Secondary School; Battery for the Evaluation of Developmental Dyslexia and Dysorthography [23] for Primary and Middle school; Evaluation Tests of Calculation Ability for Primary School [24] and Evaluation Tests of Calculation Ability and Problem Solving for Middle School [25].

Visual motor abilities were evaluated by using the Visual Motor Integration Developmental test [26].

Language was evaluated with the following tests, validated for the Italian language: Test for the Evaluation of Language [27] and Evaluation Test for the Language Comprehension [28].

Psychopathological evaluation included the following tests, assessing behavioral, anxiety, mood and interpersonal problems: Child Behaviour Checklist (CBCL, Achenbach, 2001) [29]; Kiddies Schedule for Affective Disorders and Schizophrenia for School-Age Children Present and Lifetime Version (Kaufman et al. 2004) [30]; Screen for Childhood Anxiety Related Disorders [31]; Children Depression Inventory [32]; Conner's Parent Rating Scale - Revised-Long Version [33]; Swanson Nolan and Pelham-IV [34].

The tests assessing cognitive level, skills of reading, writing and arithmetic and the CBCL were administered to all patients. The other listed tests were administered case by case to support diagnosis of neurodevelopmental and psychopathological disorders.

\section{Statistical analysis}

All demographic and clinical variables were subjected to statistical analysis. Descriptive analysis was carried out 
for the sociodemographic characteristics of the two samples. To compare age and gender between SLD and LD NOS group, we used respectively Student's $t$ tests and Chi-square independence $(x 2)$ test. In order to examine the difference of neuropsychopathological comorbidities in a sample of SLD children compared with LD NOS children, the Chi-square independence was used. Statistical significance was considered for $\mathrm{p}$-values $\leq 0.05$. We used the Software Statistical Package for Social Science version 20 .

\section{Results}

The sample included 448 Caucasian patients (319 males and 129 females) aged from 7 to 16 years (mean age 10.45, DS \pm 2.57 ). The SLD subgroup included 240 patients (53.5\%), mean age of 10.39 years, $\mathrm{SD} \pm 2.45$. The subgroup of LD NOS included 208 subjects (46.4\%), mean age of 10.2 years, $\mathrm{SD} \pm 2.67$.

Normal intellectual functioning was present in $218 \mathrm{pa}-$ tients (48.6\%), borderline intellective functioning in 68 (16.2\%), mild intellectual impairment in 132 (31.4\%) and moderate intellectual impairment in 30 (7.2\%).

In total sample, comorbidity with one or more neuropsychopathologies was found in 279 patients $(62.2 \%)$. In SLD subgroup, one or more neuropsychopathological comorbidity were present in 140 patients (58.3\%): Attention Deficit Hyperactivity Disorder (ADHD) combined or isolated in 63 (33\%), 55 males and 8 females, Anxiety Disorder in 55 (28.8\%), 39 males and 16 females, Language Disorder in 21 (11\%), 18 males and 3 females, Developmental Coordination Disorder in 34 (17.8\%), 30 males and 4 females, Mood Disorder in 18 (9.4\%), 14 males and 4 females.

In LD NOS subgroup, one or more neuropsychopathological comorbidity were present in 139 patients (66.8\%): Language Disorder in 54 (28.6\%), 36 males and 18 females, Developmental Coordination Disorder in 52 (27.5\%), 34 males and 18 females, Attention Deficit Hyperactivity Disorder (ADHD) combined or isolated in 48 (25.4\%), 41 males and 7 females, Anxiety Disorder in 31 (16.4\%), 16 males and 15 females, Mood Disorder in 4 (2.1\%), 2 males and 2 females.

Statistically significant differences between the group of SLD and LD NOS for the presence of comorbidities $(\mathrm{p}=0.64)$ did not emerge.

Considering each comorbidity, in the LD NOS subgroup, language and coordination disorders were more frequent with a statistical significant difference $(p=0.00)$; in the SLD subgroup, ADHD, anxiety and mood disorders comorbidity were more frequent with a statistical significant difference $(\mathrm{p}=0.00)$.

Neuropsychopathological comorbidities in both subgroups are summarized in Table 1.
Table 1 Neuropsycopathological comorbidity in SLD ${ }^{1}$ and LD NOS ${ }^{2}$ subgroups

\begin{tabular}{|c|c|c|c|}
\hline & SLD & LD Nos & $p$ \\
\hline Number & 240 & 208 & - \\
\hline \multicolumn{4}{|l|}{ Gender } \\
\hline Male & 184 & 135 & - \\
\hline Female & 56 & 73 & - \\
\hline Age (mean $\pm s d)$ & $10.3 \pm 2.45$ & $10.2 \pm 2.67$ & - \\
\hline Total Comorbidity \% & $58.3 \%$ & $66.8 \%$ & 0.64 \\
\hline ADHD & $33 \%$ & $25.4 \%$ & $0.00^{*}$ \\
\hline Anxiety disorder & $28.8 \%$ & $16.4 \%$ & $0.00^{*}$ \\
\hline Mood disorder & $9.4 \%$ & $2.1 \%$ & $0.00^{*}$ \\
\hline Language disorder & $11 \%$ & $28.6 \%$ & $0.00^{*}$ \\
\hline Motor coordination disorder & $17.8 \%$ & $27.5 \%$ & $0.00^{*}$ \\
\hline
\end{tabular}

${ }^{1}$ Specific Learning Disorders; ${ }^{2}$ Learning Disorders Not Otherwise Specified; * $p<0.005$.

\section{Discussion and conclusions}

The epidemiology of LD is highly variable according to the type of LD, the spoken language and the tools used for the diagnosis. International epidemiological studies report a prevalence of $4-17 \%$ for dyslexia, $2-8 \%$ for dysorthography and $1-5 \%$ for dyscalculia [35-39]. SLD are more frequent in males than females $[37,40]$.

Different languages have different writing systems and variations in prevalence depend on factors like the spelling opacity of each language. The Italian language has a shallow orthographical system, for this reason, we would expect a lower prevalence of SLD in Italy, where, however, the prevalence range is very large, between $0.88 \%$ and $10 \%$ [41-46]. In Italy, SLD represent about $30 \%$ of the users of local Neuropsychiatry Services and about $50 \%$ of patients which undergo rehabilitation [47].

Comorbidity are very common in Neuropsychiatric diseases, including LD, during developmental age. Understanding comorbidity is important because the presence of an additional disorder may affect the expression and severity of the clinical picture, requiring specific treatments and interventions. Patients with comorbidity compared to those without comorbidity usually exhibit more severe neurocognitive impairment, negative academic experience and social outcomes and lower treatment response.

Dyslexia is the most extensively investigated learning disorder in the national and international studies regarding its features and also its comorbidity.

Language disorders may precede or be associated with dyslexia. International studies have estimated that $30-40 \%$ of children with Specific Language Disorder receive a diagnosis of reading disorder later on [48-50] and a percentage between 55\% [51] and 77\% [52] of dyslexics meets the diagnostic criteria for Specific Language Disorder. In Italy, comorbidity with Specific Language Disorder has 
been found from $15 \%$ to $20 \%$ of dyslexic children $[53,54]$. These data support the hypothesis that Language Disorder and Dyslexia may have common genetic or etiologic factors and may be different manifestations of the same cognitive impairment [55-58].

In addition, children with LD often present motor, sensory, perceptual abnormalities [59-63]. Huc Chabrolle et al. [15] in a review found that the impairment of motor development is a feature of nearly $50 \%$ of patients with dyslexia and that dyslexia is common among dyspraxic patients. Motor coordination disorder was reported in a percentage from $10.3 \%$ to $26 \%$ of dyslexics [53,54]. These data support the "cerebellar theory" of dyslexia [64] according to which, the cerebellum, that is responsible for motor control and automate overlearned tasks (i.e. reading), in LD may exert an insufficient motor control influencing articulation, phonological representation and ability to form appropriate connections between graphemes and phonemes.

Comorbidity with other disorders also is known in LD. It is reported that approximately $60 \%$ of patients with dyslexia also meet the criteria for at least one neuropsychiatric disorder [65,66]. Comorbidity with ADHD is present from $10 \%$ to $50 \%$ of LD children, while comorbidity with dyslexia is present from 25 to $40 \%$ of ADHD patients [65,67-69]. Comorbidity with anxiety and mood disorders has been reported in some studies but in others no difference was detected in the symptoms of anxiety and depressed mood among children with and without LD [53,67,70-75].

We did not find comparative data between SLD and LD NOS in literature.

In our sample we detected a comorbidity with neuropsychopathological disorders in both analyzed subgroups with some differences. A more significant presence of language and motor coordination disorders was found in the LD NOS compared to SLD subgroup. This could be linked to a higher degree of functional impairment in LD NOS patients, which presented, in the majority of cases, intellectual disability that might interfere with the normal evolution of neurolinguistic and motor development.

A meaningful presence of ADHD, anxiety and depressed mood was detected in the SLD subgroup. Some old and less replicated studies have suggested that reading disorder might be the primary deficit which causes secondary symptoms of ADHD [76-79]. Recent data have shown that there are common cognitive deficits between the two disorders [80] according to a possible similar genetic etiology, as demonstrated by families studies in twins $[81,82]$. Our results might support these latter theories, as demonstrated by the higher frequency of ADHD in SLD patients. With regards to anxiety and depressed mood, a bi-directional relationship between anxiety, depression and academic achievement has recently been hypotized [83].
Anxiety and depressed mood could negatively impact learning process, alternatively children with LD may develop anxiety and mood problems, because they often reported adverse academic experiences. In our study we can assume that the symptoms of anxiety and depression are more frequent in the SLD subgroup, due to the greater introspective capacities of these children which are more aware of their difficulties compared to LD NOS patients, most of which have cognitive impairments.

In May 2013, it was published the DSM-5 [84] that provides the diagnostic category of LSD as a single, overall diagnosis. New criteria give detailed specifiers for the areas of reading, mathematics and written expression and specifiers for grade of severity (mild, moderate, severe). The classification system DSM-5 does not provide diagnostic category LD unspecified/NOS but admit that SLD can cooccurs with neurodevelopmental (e.g. ADHD, communication disorders, developmental coordination disorder, autistic spectrum disorder) or other mental disorders (e.g. anxiety disorders, depressive and bipolar disorders). Further investigations, in according to new classification criteria, are need to better define comorbidities and LSD prognostic profiles to implement appropriate intervention strategies.

\section{Competing interests}

We confirm that we have read the journal's position on issues involved in ethical publication and affirm that this report is consistent with those guidelines.

None of the authors has any competing interest to disclose.

All co-authors have seen and approved the final version of the paper and accept responsibility for the data presented.

There is no financial or others conflict of interest that may be related to the authors.

\section{Authors' contributions}

LM conceived of the study and participated in final approval of the version to be published, MB conceived of the study and participated in its design and coordination and helped to draft the manuscript, FC participated in the design of the study and performed the statistical analysis, AC carried out substantial contributions to conception, design and acquisition of data, CdG carried out substantial contributions to conception, design and acquisition of data, EM participated in the sequence alignment and drafted the manuscript FO carried out contributions to interpretation of data, MS carried out contributions to conception and design and acquisition of data. All authors have seen and approved the final version of the paper and accept responsibility for the data presented.

Received: 26 August 2013 Accepted: 4 December 2013 Published: 13 December 2013

\section{References}

1. Buonincontri R, Bache I, Silahtaroglu A, Elbro C, Nielsen AM, Ullmann R, Arkesteijn G, Tommerup N: A cohort of balanced reciprocal translocations associated with dyslexia: identification of two putative candidate genes at DYX1. Behav Gen 2011, 41(1):125-33.

2. König IR, Schumacher J, Hoffmann P, Kleensang A, Ludwig KU, Grimm T, Neuhoff N, Preis M, Roeske D, Warnke A, Propping P, Remschmidt H, Nöthen MM, Ziegler A, Müller-Myhsok B, Schulte-Körne G: Mapping for dyslexia and related cognitive trait loci provides strong evidence for further risk genes on chromosome 6p21. Am J Med Genet B Neuropsychiatr Genet 2011, 156B(1):36-43. 
3. Meng H, Powers NR, Tang L, Cope NA, Zhang PX, Fuleihan R, Gibson C, Page GP, Gruen JR: A dyslexia-associated variant in DCDC2 changes gene expression. Behav Gen 2011, 41(1):58-66.

4. Poelmans G, Engelen JJ, Van Lent-Albrechts J, Smeets HJ, Schoenmakers E, Franke B, Buitelaar JK, Wuisman-Frerker M, Erens W, Steyaert J, SchranderStumpel C: Identification of novel dyslexia candidate genes through the analysis of a chromosomal deletion. Am J Med Genet B Neuropsychiatr Genet 2009, 150B:140-147.

5. Poelmans G, Buitelaar JK, Pauls DL, Franke B: A theoretical molecular network for dyslexia: integrating available genetic findings. Mol Psychiatry 2011, 16:365-382.

6. Giraud AL, Ramus F: Neurogenetics and auditory processing in developmental dyslexia. Curr Opin Neurobiol 2013, 23(Supp 1):37-42.

7. Aarnoudse-Moens CSH, Weisglas-Kuperus N, van Goudoever JB, Oosterlaan $\mathrm{J}$ : Meta-analysis of neurobehavioral outcomes in very preterm and/or very low birth weight children. Pediatrics 2009, 124(Supp 2):717-28.

8. De Rodrigues M, Mello RR, Fonseca SC: Learning difficulties in schoolchildren born with very low birth weight. J Pediatr (Rio J) 2006, 82(1):6-14.

9. Wang WL, Sung YT, Sung FC, Lu TH, Kuo SC, Li CY: Low birth weight, prematurity, and paternal social status: impact on the basic competence test in Taiwanese adolescents. J Pediatr 2008, 153(Supp 3):333-8.

10. Fried PA, Watkinson B, Siegel LS: Reading and language in 9-to 12-year olds prenatally exposed to cigarettes and marijuana. Neurotoxicol Teratol 1997, 19(Supp 3):171-83.

11. Wilder RT, Flick RP, Sprung J, Katusic SK, Barbaresi WJ, Mickelson C, Gleich SJ, Schroeder DR, Tessitore AL, Warner DO: Early exposure to anesthesia and learning disabilities in a population-based birth cohort. Anesthesiology 2009, 110(Supp 4):796-804.

12. Sprung J, Flick RP, Wilder RT, Katusic SK, Pike TL, Dingli M, Gleich SJ, Schroeder DR, Barbaresi WJ, Hanson AC, Warner DO: Anesthesia for cesarean delivery and learning disabilities in a population-based birth cohort. Anesthesiology 2009, 111(Supp 2):302-10.

13. Martin CS, Romig CJ, Kirisci L: DSM-IV learning disorders in 10- to 12-year-old boys with and without a parental history of substance use disorders. Prev Sci 2000, 1(Suppl 2):107-13.

14. Morrow CE, Culbertson JL, Accornero VH, Xue L, Anthony JC, Bandstra ES: Learning disabilities and intellectual functioning in school-aged children with prenatal cocaine exposure. Dev Neuropsychol 2006, 30(Suppl 3):905-31.

15. Huc Chabrolle M, Barthez MA, Tripi G, Barthelemy C, Bonnet-Brilhault F: Psychocognitive and psychiatric disorders associated with developmental dyslexia: A clinical and scientific issue. Encéphale 2010, 36(Suppl 2):172-9.

16. American Psychiatric Association: Diagnostic and Statistical Manual of Mental Disorders, Fourth Edition (DSM-IV). Washington DC: American Psychiatric Publishing; 2000.

17. Wechsler D: Wechsler intelligence scale for children. 3rd edition. Firenze: Organizzazioni Speciali; 2006

18. Wechsler D: Wechsler intelligence scale for children. 4th edition. Firenze: Organizzazioni Speciali; 2012.

19. Roid GH, Miller LJ: Leiter International Performance Scale-Revised. Firenze: Organizzazioni Speciali; 2002.

20. Cornoldi C, Colpo G: Prove di lettura MT per la scuola elementare. Firenze: Organizzazioni Speciali; 1998.

21. Cornoldi C, Colpo G: Nuove prove di lettura MT per la scuola media inferiore. Firenze: Organizzazioni Speciali; 1995

22. Cornoldi C, Pra Baldi A, Friso G, Giacomin A, Giofrè D, Zaccaria S: Prove MT Avanzate di Lettura e Matematica 2 per il biennio della scuola superiore di II grado. Firenze: Organizzazioni Speciali; 2010

23. Sartori G, Job R, Tressoldi PE: Batteria per la valutazione della dislessia e della disortografia in età evolutiva. Firenze: Organizzazioni Speciali; 1995.

24. Cornoldi C, Lucangeli D, Bellina M: Test AC-MT. Test di valutazione delle abilità di calcolo. Gruppo MT. Trento: Centro Studi Erickson; 2002.

25. Cornoldi C, Cazzola C: Test di valutazione delle abilità di calcolo e problem solving dagli 11 ai 14 anni. Gardolo-Trento: Edizioni Erickson; 2003.

26. Beery KE, Buktenica NA: Developmental test of visual motor integration. Firenze: Organizzazioni Speciali; 2000.

27. Cianchetti C, Sannio Fancello G: TVL/ Test di valutazione del linguaggio. Trento: Erickson Edizioni; 1997.

28. Rustioni Metz LD: Prova di valutazione della comprensione linguistica. Firenze: Organizzazioni Speciali; 1994
29. Achenbach MT: Child behavior checklist for ages 6-18. ASEBA: University of Vermont; 2001.

30. Kaufman J, Birmaher B, Brent D, Rao U, Ryan N: K-SADS-PL, Intervista diagnostic per la valutazione dei disturbi psicopatologici in bambini e adolescenti. Gardolo-Trento: Edizioni Erickson; 2004.

31. Birmaher B, Khetarpal S, Brent D, Cully M, Balach L, Kaufman J, McKenzie Neer S: The Screen for Child Anxiety Related Emotional Disorders (SCARED): scale construction and psychometric characteristics. J Am Acad Child Adolesc Psychiatry 1997, 36:545-553.

32. Kovacs M: Children's Depression inventory, questionario di autovalutazione Firenze: Organizzazioni Speciali; 1988.

33. Conners CK: Conners' Rating scales - revised. Firenze: Organizzazioni Speciali; 2007.

34. Swanson JM: Teacher and parent rating scale. Irvine, CA: KC Publishing; 1992.

35. Forness SR, Kavale KA: Treating social skill deficits in children with learning disabilities: a meta-analysis. Learn Disabil 1996, 19:80-89.

36. Démonet JF, Taylor MJ, Chaix Y: Developmental dyslexia. Lancet 2004, 363(Suppl 9419):1451-1460.

37. Rutter M, Caspi A, Fergusson D, Horwood LJ, Goodman R, Maughan B, Moffitt TE, Meltzer H, Carroll J: Sex differences in developmental reading disability: new findings from 4 epidemiological studies. JAMA 2004, 291(Suppl 16):2007-12

38. INSERM Collective Expert Reports: Dyslexia, dysorthography, dyscalculia. Review of the scientific data. Paris: Institut national de la santé et de la recherche médicale; 2007.

39. Shalev RS: Developmental dyscalculia. J Child Neurol 2004, 19(Suppl 10):765-71.

40. Hawke JL, Olson RK, Willcut EG, Wadsworth SJ, DeFries JC: Gender ratios for reading difficulties. Dyslexia 2009, 15(Suppl 3):239-42.

41. Mazzotta G, Arcangeli L, Falcinelli F, Lollini P, Vergimigli M, Gallai V: II disturbo di lettura: indagine sugli alunni della III elementare del Comune di Perugia e considerazioni neuro-psico-pedagogiche. Ann Med Perugia 1992, 83:111-123

42. Levi G, Meledandri G: Epidemiologia dei disturbi psicopatologici nell'età evolutiva (Parte II). Modena: Federazione Medica 14, ARBE; 1994.

43. Stella G: Dislessia evolutiva. Giornale di Neuropsichiatria dell' Età Evolutiva 1999, 19:39-52.

44. Coscarella C: Epidemiologia dei deficit specifici di apprendimento nel territorio dell'Isola d'Elba. Psichiatria dell' Infanzia e dell' Adolescenza 2001, 68:7-15.

45. Tressoldi PE, Stella G, Faggella M: The development of reading speed in Italians with Dyslexia: a longitudinal study. J Learn Disabil 2001, 34:67-78

46. Barbiero C, Lonciari I, Montico M, Monasta L, Penge R, Vio C, Epidemiology of Dyslexia of Friuli Venezia Giulia working group (FVGwg), et al: The submerged dyslexia iceberg: how many school children are not diagnosed? Results from an Italian study. PLoS One 2012, 7(Suppl 10):e48082.

47. Consensus Conference, Ministero della Salute: Disturbi specifici dell'apprendimento. ; 2011. Available online on http://www.snlg-iss.it.

48. Snowling M, Bishop DVM, Stothard SE: Is pre-school language impairment a risk factor for dyslexia in adolescent? J Child Psychol Psychiatry 2000, 41:587-600.

49. Catts HW, Fey ME, Tomblin JB: A longitudinal investigation of reading outcomes in children with language impairments. J Speech Lang Hear Res 2002, 45:1142-1157.

50. Smiths S, Pennington B, Boada R, Shriberg LD: Linkage of speech sound disorder to reading disability loci. J Child Psychol Psychiatr 2005, 46:1057-66.

51. Mcarthur GM, Hogben JH, Edwards VT, Heath SM, Mengler ED: On the "specifics" of specific reading disability and specific language impairment. J Child Psychol Psychiatr 2000, 41:869-874.

52. Ramus F, Pidgeon E, Frith U: The relationship between motor control and phonology in dyslexic children. J Child Psychol Psychiatry 2003, 44(Suppl 5):712-22.

53. Gagliano A, Germanò E, Calabrese T, Magazù A, Grosso R, Siracusano RM, Cedro C: La comorbidità nella dislessia: studio di un campione di soggetti in età evolutiva con disturbo di lettura. Dislessia 2007, 4:21-39.

54. Stella G, Franceschi S, Savelli E: Disturbi associati nella dislessia evolutiva. Uno studio preliminare. Dislessia 2009, 6:1.

55. Bishop DVM, Snowling MJ: Developmental dyslexia and specific language impairment: same or different? Psychol Bull 2004, 130:858-886. 
56. Catts HW, Adlof SM, Hogan TP, Weismer SE: Are specific language impairment and dyslexia distinct disorders? J Speech Lang Hear Res 2005, 48:1378-1396

57. Pennington BF, Bishop DV: Relations among speech, language and reading disorders. Annu Rev Psychol 2009, 60:283-306.

58. Newbury DF, Paracchini S, Scerri TS, Winchester L, Addis L, Richardson AJ, Walter J, Stein JF, Talcott JB, Monaco AP: Investigation of dyslexia and SLI risk variants in reading- and language-impaired subjects. Behav Genet 2011, 41(Suppl 1):90-104

59. Capellini SA, Coppede AC, Valle TR: Fine motor function of school-aged children with dyslexia, learning disability and learning difficulties. Prò-Fono Revista de Atualizacao Cientifica 2010, 22:3.

60. Lingam R, Golding J, Jongmans MJ, Hunt LP, Ellis M, Emond A: The association between developmental coordination disorder and other developmental traits. Pediatrics 2010, 126(Suppl 5):1109-18.

61. van Roon D, Caeyenberghs K, Swinnen SP, Smits-Engelsman BC: Children with a learning disorder show prospective control impairments during visuomanual tracking. Res Dev Disabil 2010, 31(Suppl 1):195-202.

62. Pieters $S$, Desoete $A$, Van Waelvelde $H$, Vanderswalmen $R$, Roeyers $H$ : Mathematical problems in children with developmental coordination disorder. Res Dev Disabil 2012, 33(Suppl 4):1128-35.

63. Westendorp M, Hartman E, Houwen S, Smith J, Visscher C: The relationship between gross motor skills and academic achievement in children with learning disabilities. Res Dev Disabil 2011, 32(Suppl 6):2773-9.

64. Fawcett AJ, Nicolson Rl: From Dyslexia: The role of the cerebellum. In Dyslexia in context: research, policy and practice. Chapter 2. Edited by Reid G, Fawcett AJ. London: Whurr Publishers; 2004.

65. Willcutt E, Pennington B, DeFries JC: Twin study of the aetiology of comorbidity between reading disability and attention-deficit/hyperactivity disorder. Am J Med Genet 2000, 96:293-301.

66. Trzienewski K, Moffitt T, Caspi A, Taylor A, Maughan B: Revisiting the association between reading achievement and antisocial behavior: new evidence of an environmental explanation from a twin study. Child Dev 2006, 77:72-88.

67. Carroll JM, Maughan B, Goodman R, Meltzer H: Literacy difficulties and psychiatric disorders: evidence for comorbidity. J Child Psychol Psychiatr 2005, 46(Suppl 5):524-532.

68. Kain W, Landerl K, Kaufmann L: Comorbidity of ADHD. Monatsschr Kinderheilkd 2008, 8:757-767.

69. Langberg JM, Vaught AJ, Brinkman WB, Froehlich T, Epstein JN: Clinical utility of the Vanderbilt ADHD Rating Scale for ruling out comorbid learning disorders. Pediatrics 2010, 126:1033-1038.

70. Arnold EM, Goldston DB, Walsh AK, Reboussin BA, Daniel SS, Hickman E, Wood FD: Severity of emotional and behavioral problems among poor and typical readers. J Abnorm Child Psychol 2005, 33:205-17.

71. Li H, Morris RJ: Assessing fears and related anxieties in children and adolescents with learning disabilities or mild mental retardation. Res Dev Disabil 2007, 28(Suppl 5):445-57.

72. Terras MM, Thompson LC, Minnis H: Dyslexia and psycho-social functioning: an exploratory study of the role of self-esteem and understanding. Dyslexia 2009, 15(Suppl 4):304-27.

73. Kempe C, Gustafson S, Samuelsson S: A longitudinal study of early reading difficulties and subsequent problem behaviors. Scand J Psychol 2011, 52(Suppl 3):242-50.

74. Nelson JM, Gregg N: Depression and anxiety among transitioning adolescents and college students with ADHD, dyslexia, or comorbid ADHD/dyslexia. J Atten Disord 2012, 16(Suppl 3):244-54.

75. Rietz CS, Hasselhorn M, Labuhn AS: Are externalizing and internalizing difficulties of young children with spelling impairment related to their ADHD symptoms? Dyslexia 2012, 18(Suppl 3):174-85.

76. Cunningham CE, Barkley RA: The role of academic failure in hyperactive behaviour. J Learn Disabil 1978, 11:15-21.

77. Rabiner D, Coie JD, the Conduct Problems prevention Research Group: Early attention problems and children's reading achievement: a longitudinal investigation. J Am Acad Child Adolesc Psychiatry 2000, 39:859-867.

78. McGee R, Prior M, Williams S, Smart D, Sanson A: The long-term significance of teacher-rated hyperactivity and reading ability in childhood: findings from two longitudinal studies. J Child Psychol Psychiatr 2002, 43:1004-1017.

79. Dally K: The influence of phonological processing and inattentive behaviour on reading acquisition. J Educ Psychol 2006, 98:420-437.
80. Willcutt EG, Betjemann RS, McGrath LM, Chhabildas NA, Olson RK, DeFries JC, Pennington BF: Etiology and neuropsychology of comorbidity between RD and ADHD: The case for multiple-deficit models. Cortex 2010, 46(Suppl 10):1345-61.

81. Ebejer JL, Coventry WL, Byrne B, Willcutt EG, Olson RK, Corely R, Sammuelson S: Genetic and environmental influences on inattention, hyperactivity-impulsivity and reading: Kindergarten to grade 2 . Sci Stud Read 2010, 14:293-316.

82. Greven CU, Rijsdijk FV, Asherson P, Plomin R: A longitudinal twin study on the association between ADHD symptoms and reading. J Child Psychol Psychiatry 2012, 53(Suppl 3):234-42.

83. Grills-Tacquerel AE, Fletcher JM, Vaughn SR, Stuebing KK: Anxiety and reading difficulties in early elementary school: evidence for unidirectional or bidirectional relations? Child Psychiatr Hum Dev 2012, 43(Suppl 1):35-47.

84. American Psychiatric Association: Diagnostic and Statistical Manual of Mental Disorders, Fifth Edition (DSM-5). Washington DC: American Psychiatric Publishing; 2013

doi:10.1186/1471-2377-13-198

Cite this article as: Margari et al:: Neuropsychopathological

comorbidities in learning disorders. BMC Neurology 2013 13:198.

\section{Submit your next manuscript to BioMed Central and take full advantage of:}

- Convenient online submission

- Thorough peer review

- No space constraints or color figure charges

- Immediate publication on acceptance

- Inclusion in PubMed, CAS, Scopus and Google Scholar

- Research which is freely available for redistribution

Submit your manuscript at www.biomedcentral.com/submit
C) BioMed Central 